23. Knickerbocker H.R. The Red Trade Menace. Progress of the Soviet Five Year Plan. New York: Dodd, Mead and Company, 1931.277 p.

24. Lyons E. Assignment in Utopia. New York: Harcourt, Brace and Company, 1937. $681 \mathrm{p}$.

25. Chamberlin W.H. Russia's Iron Age. Boston: Little, Brown and Company, 1934. 389 p.

26. Дьюи Д. Впечатления о советской России и революционном мире // История философии. 2000. № 5. C. 224-269.

27. Hirsch A. Industrialized Russia. Chemical Catalog Company, 1934. 309 p.

28. Sigerist H.E. Socialized Medicine in the Soviet Union. New York: W.W. Norton \& Company, Inc., $1937.378 \mathrm{p}$.

29. Письмо Народного комиссара внешней и внутренней торговли СССР А.И. Микояна члену коллегии НКВТ И.О. Шлейферу о пропаганде СССР в американской печати от 26 июля 1927 г. // Советскоамериканские отношения. Годы непризнания. 19271933 / под ред. Г.Н. Севостьянова. М.: Международный фонд «Демократия», 2002. С. 37-38.

30. История США. Т. 3 / под ред. Г.Н. Севостьянова. М.: Наука, 1983. 336 с.

31. Макаров А.Н. «Советские рабочие живут лучше, чем раньше»: взгляд иностранца на индустриали- зацию 1930-х гг. сквозь призму советского фоторепортажа // Исторический журнал History Illustrated. 2011. № 3. C. 54-65.

32. Bourke-White M. Eyes on Russia. New York: Simon and Schuster, 1931. $135 \mathrm{p}$.

33. Abbe J.E. I photograph Russia. R. M. McBride, 1934. $312 \mathrm{p}$.

34. Подлужная А.М. Внешняя цензура в России в 1920-е-1930-е гг. // Известия ПГПУ им. В.Г. Белинского. 2012. № 27. С. 899-904.

35. Правила пропуска за границу предметов, подлежащих рассмотрению органами Главлита от 29 апреля 1929 г. // Цензура в Советском Союзе. 19171991. Документы / сост. А.В. Блюм. М.: Российская политическая энциклопедия (РОССПЭН), 2004. C. $159-160$.

36. Тихий К.Т. Роль цензуры и самоцензуры в работе американских обозревателей в Советском Союзе в 1920-1930-е годы // Гуманитарные исследования в Восточной Сибири и на Дальнем Востоке. 2012. № 1. C. 26-31.

37. Блюм А.В. Советская цензура в эпоху тотального террора. 1929-1953. СПб.: Гуманитарное агентство «Академический проект», 2000. С. 36-44.

38. Duranty W. Soviet censorship hurts Russia most // The New York Times. June 23, 1931.

\title{
THE AMERICAN PRESS ABOUT THE SOVIET INDUSTRIALIZATION IN 1920-1930S
} (C) 2016

O.O. Rezanenko, postgraduate student of the Chair of International Relations and Foreign Area Studies Volgograd State University, Volgograd (Russia)

Abstract. Press releases' nature about the soviet industrialization, business and political circles' and intellectuals' reaction to the changes in the USSR during the 1920-1930s and deciding factors of the five-year plans perception by the Americans are determined and analyzed in this work. American periodicals, diplomatic correspondence of the People's Commissariat for Foreign Affairs (NKID) as well as materials of soviet propaganda are of particular importance for this research. On the basis of these sources the following conclusions were drawn: the American public had different views on the Soviet industrialization. Positive estimations were based on the real progress (new plants' construction, improvement of the quality of life). Negative - on disparities between Soviet and American standards of labor productivity and quality, management, discipline, etc. Authors' personal sympathies to the Soviet regime, artificial information selection by soviet censorship, political, social and economic environment in the USA influenced on the American public opinion. Soviet propaganda methods in order to form proper views in American society in that period were not substantial.

Keywords: soviet-american relations; American public opinion; industrialization; five-year plans; global economic crisis; technical assistance; American specialists; anti-Soviet campaign; dumping; American intellectuals; soviet propaganda; soviet censorship.

\section{УСЛОВИЯ ВЫПОЛНЕНИЯ СОВЕТСКИХ ИСТОРИЧЕСКИХ ИССЛЕДОВАНИЙ ПО ПРОБЛЕМАТИКЕ ИСТОРИИ ГРАЖДАНСКОЙ ВОЙНЫ В РОССИИ (1918-1922 ГГ.) ВО ВТОРОЙ ПОЛОВИНЕ 1950-Х - ПЕРВОЙ ПОЛОВИНЕ 1960-Х ГОДОВ}

(C) 2016

Г.М. Ипполитов, доктор исторических наук, профессор кафедры философии Поволжский государственный университет телекоммуникаций и информатики, Самара (Россия)

В.Я. Ефремов, доктор исторических наук, профессор кафедры социально-гуманитарных дисциплин Вольский военный институт материального обеспечения (филиал) Военной академии материально-технического обеспечения имени генерала армии А.В. Хрулева Министерства оборонь Российской Федераџии, Вольск (Россия)

Аннотащия. «Хрущевская оттепель» - уникальный период в истории Советского государства. Это было десятилетие, когда предпринимались попытки, по крайней мере, локализации тех негативных последствий, которые были порождены сталинской политической системой, функционировавшей в стране (так называемого 
«культа личности Сталина»). От негативных последствий властные структуры СССР и правившая в стране коммунистическая партия пытались очистить все сферы жизни советского социума, в том числе и духовную. Коснулось это в полной мере и советской исторической науки. В ней предпринимались попытки выполнения исторических, историографических, источниковедческих исследований на принципах подлинной объективности и историзма (правда, такие попытки остались в конечном итоге в форме зачаточных тенденций, которые постепенно ликвидировались). В такой историографической ситуации в числе приоритетных направлений оставалось исследование истории российской Гражданской войны (ноябрь 1917-1922), в том числе и в ключе проблемно-тематической историографии. В статье в конспективной форме намечены контуры основных условий, в которых развивалось исследование Гражданской войны в России в период хрущевской оттепели (вторая половина 1950-х - первая половина 1960-х гг.). Отдельные тезисы, выдвигаемые авторами статьи, носят дискуссионный характер.

Ключевые слова: историография; советская историческая наука; Гражданская война в России; ХХ съезд КПСС (1956 г.); хрущевская оттепель; прорыв в источниковой базе исследований; сборники документов; цензурные идеологические ограничения.

Аксиоматично, что деятельность ученых-историков напрямую зависит от условий, в которых они занимаются научным творчеством. Причем вне зависимости от политического режима, господствующего в стране. Но в условиях Советского государства, в силу конкретно-исторической обстановки (эволюция тоталитарного политического режима сталинизма в авторитарно-бюрократический политический режим $[1 ; 2 ; 3])$, подобная зависимость прослеживается особенно рельефно. Не случайно, например, в современных отечественных проблемно-тематических историографических исследованиях ученые акцентируют внимание на освещении ситуации, складывавшейся в тот или иной историографический период $[4 ; 5 ; 6 ; 7]$.

В данной статье авторы кратко раскрывают условия выполнения советских исторических исследований по проблематике истории Гражданской войны в России (1918-1922 гг.) во второй половине 1950-х первой половине 1960-х гг. Такие хронологические рамки историографического анализа подразумевают освещение периода в истории нашей державы и ее исторической науки, который получил название «хрущевская оттепель».

Ее породил ХХ съезд КПСС (1956 г.), когда на нем Н.С. Хрущев в секретном докладе оголил страшную правду о временах культа личности И.В. Сталина [8]. Этот доклад сыграл в какой-то мере роль горького лекарства, которое больной, морщась, выпивает, чтобы выздороветь. И хотя (теперь это уже не вызывает сомнения) хрущевская правда о мрачных временах культа личности И.В. Сталина была рафинированной, в советском социуме она буквально вызывала шок. Следом началась мучительная переоценка ценностей, ломавшая души, например, поколения «шестидесятников» (многие из них впоследствии стали на путь диссидентства [9]). Хрущевская оттепель - время мечтаний и несбывшихся надежд [10]. Его главное содержание обусловливалось, если говорить обобщенно, конструктивными процессами в экономической, социально-политической и духовной жизни страны. Но хотя облик страны благодаря циклу реформ преобразился, крупного прорыва в новое качество не произошло. Налицо сплошной узел противоречий, которые так и не удалось разрешить: слишком цепко мертвый Сталин держал Хрущева и его единомышленников за ноги $[11 ; 12$, с. 86-95; 13, c. 208-227].

Конечно, конкретные события не могли в самом общем плане не влиять, причем достаточно противо- речиво, на развитие советской исторической науки в период хрущевской оттепели. Ведь историческая наука - часть духовной жизни социума. В это время советская историография начала развиваться под влиянием политического курса КПСС на преодоление последствий культа личности И.В. Сталина. В условиях зачаточной реанимации творческой свободы, как одного из знаковых признаков хрущевской оттепели, предпринималась попытка возродить подлинно научные принципы исторических исследований.

Руководствуясь решениями ХX съезда КПСС (1956 г.), ученые-обществоведы и гуманитарии сосредоточили внимание на создании трудов, особенно по истории советского общества, в которых предстояло исправить деформации, порожденные периодом культа личности И.В. Сталина. Причем для развития решений ХХ съезда КПСС о преодолении последствий культа личности И.В. Сталина ЦК КПСС принял ряд постановлений, направленных на дальнейшее улучшение работы историков: об издании Полного собрания сочинений В.И. Ленина (1957 г.), Исторической энциклопедии, о книгах по истории фабрик и заводов (1958 г.), о журнале «Вопросы истории КПСС». Нельзя здесь не вспомнить и о таком мероприятии, как совещание Комиссии по подготовке предложений об улучшении работы в области общественных наук при ЦК КПСС. Здесь отмечалось то, что появлялись попытки сформировать «элементарные условия для свободного мышления» [14, с. 253].

То, что задача по исправлению деформаций и искажений, порожденных в советской исторической науке культом личности И.В. Сталина, стала приоритетной, явилось условием активизации исследовательского поиска. Об этом свидетельствуют такие количественные характеристики: за период 19561960 гг. преподавателями общественных наук вузов было выпущено около 900 сборников научных трудов, защищено 722 кандидатские диссертации, из них 583 по проблематике советского периода. По вопросам индустриализации с 1956 г. опубликовано свыше трех десятков крупных работ, что в 5 раз больше, чем за все предшествующие 25 лет [6, с. 280].

Значительную роль в повышении методологической стройности научных работ сыграло Всесоюзное совещание о мерах по улучшению подготовки научно-педагогических кадров по историческим наукам, проведенное ЦК КПСС в 1962 г. Оно стимулировало обращение ученых к исследованию фундаментальных проблем советского общества. Между тем с ди- 
станции времени выглядит чрезмерно оптимистичной такая мысль, высказанная на данной форуме: «Культ личности, подобно кандалам, висел на ногах советской исторической науки, но она все же продолжала идти вперед» $[15$, с. 21]. Ведь советской исторической науке в конечном итоге не удалось выйти на качественно новые рубежи познания исторической истины: оттепель никоим образом не отменила практики декретирования со стороны ЦК КПСС научных истин в последней инстанции, навязывания ученым «классово актуальной» проблематики научной исследований.

Пример такого навязывания дал заведующий отделом науки и учебных заведений ЦК КПСС Ф.В. Константинов: «Есть на свете лишь одна подлинно научная общественно-политическая теория это марксистско-ленинское учение о классах и классовой борьбе, о государстве и революции, о диктатуре пролетариата, о законах строительства социализма и коммунизма» $[16$, с. 86]. Собственно говоря, партийный функционер перефразировал печально известного сталинского соратника в деле репрессий 1937 года Л.М. Кагановича. Тот в речи, посвященной десятилетию Института красной профессуры, говорил: «История нашей партии есть история непримиримой борьбы с уклонами от последовательных, революционных, марксистско-ленинских позиций» [17, с. 13].

Необходимо подчеркнуть, что в период оттепели практиковалась и более мягкая, но тем не менее обязательная форма навязывания методологических ориентиров исследователям - публикация передовых статей в академических журналах $[18$, с. 3-14; 19, c. 3-13].

Что характерно, по-прежнему приоритетной оставалась подготовка научных трудов в историкопартийном ключе: за период с 1956 по 1961 г. издано около 7 тыс. книг, брошюр, сборников статей по истории КПСС, что в два раза больше, чем за предыдущее пятилетие [5, с. 253].

На стройность теоретико-методологической основы исторических исследований положительное влияние оказало то, что завершилось издание Полного собрания сочинений Ленина. Правда, методологическая стройность научных трудов должна в данной связи рассматриваться через безраздельно господствовавший тогда марксизм-ленинизм, хотя и избавлявшийся от влияния культа личности И.В. Сталина, но по-прежнему догматизированный настолько, насколько было возможным, когда Марксово учение перевели в большевистское измерение.

Для преодоления последствий культа личности И.В. Сталина в методологии исторической науки сыграло значительную роль то, что в рамках работы по изданию Полного собрания сочинений Ленина оперативно публиковались в периодической печати (газете «Правда», журналах «Коммунист», «Вопросы истории», «Исторический архив» и др.) новые документы основателя Советского государства [20, с. 320; 21, с. 41-75, 22, с. 32-40]. Если с 1951 по 1956 гг. их было опубликовано 35, то в период с 1956 по 1960 гг. - более 100 [5, с. 282].

Особо следует подчеркнуть факт издания в 1959 г. XXXVI Ленинского сборника. В нем впервые увидели свет 636 документов, написанных в период с мар- та 1917 г. по январь 1923 г. Всего в течение 19561961 гг. издано около 70 новых ленинских документов по военным вопросам [23, с. 152].

Характерно и то, что в период оттепели широкое распространение получило издание отдельных трудов В.И. Ленина. К концу 1950-х гг. ленинские труды изданы на 92 языках, из них на 64 языках народов СССР и на 28 языках народов зарубежных стран. Общий тираж в нашей стране за период 1917 по 1961 г. составил 313158 тыс. экземпляров, причем на русском языке - 236724 тыс., на языках народов зарубежных стран - 18234 тыс. и на языках народов СССР - 58200 тыс. экземпляров [24, с. 27].

Конечно, с точки зрения современного уровня накопления исторических знаний нельзя не сказать о противоречивости такого отношения к публикации ленинского идейно-теоретического наследия. В советской исторической науке (да и не только в исторической) из ленинских произведений сделали своего рода фетиш. Лениниана стала использоваться для «цитатных боев» с идеологическими противниками, а также в качестве обязательного и решающего аргумента для доказательств выдвигаемых тезисов. По образному выражению отечественного философа и историка Д.А. Волкогонова, «ленинская духовная пища была также обязательна для каждого советского человека, как Коран у фундаменталистов в мусульманском мире» [25, с. 11].

Подобное положение дел нанесло в конечном итоге серьезный ущерб советской исторической науке. Сознательно не вступая в дискуссию, а тем более в полемику, так как это выходит за рамки предмета исследования данной статьи, еще раз укажем на впечатляющее по масштабам расширение публикаций произведений В.И. Ленина и то, что это, бесспорно, сыграло свою положительную роль в той конкретно-исторической обстановке.

Были также изданы новые партийные и государственные документы, имевшие большое, в первую очередь методологическое, значение для рассмотрения проблем истории Гражданской войны. Важное значение для того времени имели принятые на XXII съезде КПСС в 1961 г. Программа и Устав Коммунистической партии Советского Союза [26, с. 196-325].

Плодотворное влияние на изучение истории Гражданской войны оказали еще ряд явлений, детерминировавших развитие советской исторической науки: расширение круга субъектов научного исследования анализируемой проблемы и проведение некоторых организационно-научных мероприятий, способствовавших повышению качества научных исследований; прорыв в источниковой базе исследований; появление большого количества трудов историографического плана, в которых целевым направлением рассматривалась история изучения истории Гражданской войны, а также и ряда библиографических и научно-справочных изданий.

Расширение круга субъектов научного исследования анализируемой проблемы и проведение некоторых организационно-научных мероприятий, способствовавших повышению качества научных исследований. Изучением истории Гражданской войны (в контексте исследования идеологической деятельности РКП(б)) вплотную занялись ведущие на то время 
научные учреждения страны, такие как Институт марксизма-ленинизма при ЦК КПСС, Институт истории СССР АН СССР, Академия общественных наук при ЦК КПСС, а также многие отдельные специалисты. Кроме того, в 1957 г. начали издаваться журналы «Вопросы истории КПСС», «История СССР», «Новая и новейшая история». В 1959 г. возобновляется издание «Военно-исторического журнала». Тогда же появилось большое количество различных ученых записок и научных трудов. Не прошло бесследно и обсуждение вопросов методологии истории на расширенных заседаниях секции общественных наук Президиума АН СССР [27, с. 23-66]. Оно сыграло определенную роль в повышении методологической стройности работ (конечно, в существующей системе теоретико-методологических координат).

Прорыв в источниковой базе исследований. На фоне облегченного, правда только в некоторой степени, доступа к архивным источникам (если в 1947 г. в читальных залах системы Государственного архивного управления получили доступ к документам немногим более 4 тыс. человек, то в 1957 г. - свыше 23 тыс. [28, с. 69]), нельзя не отметить того, что большое количество документов, имеющих отношение к истории Гражданской войны, было опубликовано в тематических сборниках [29; 30; 31]. Выходили они в свет и в научной периодике [32, с. 132-155; 33 , с. 26-40]. Это стало выражением общей тенденции в советской историографии периода хрущевской оттепели - освоения новых документальных и архивных фондов. Введение в научный оборот ранее недоступных документальных материалов - наиболее существенное завоевание тех лет в советской исторической науке. За пять лет - с 1956 по 1960 гг. - издано около 500 сборников документов [34, с. 407].

Без преувеличения можно сказать: огромную ценность для исследователей проблематики, которой посвящена наша статья, представляет сборник «Из истории гражданской войны в СССР», изданный в 1960-1963 гг., где опубликовано 2172 документа [35]. По мнению составителей характеризуемого сборника, в нем впервые собраны документы, охватывающие все главные события страны в годы Гражданской войны. Здесь впервые были опубликованы документы союзнического комитета Антанты, обнаруженные среди германских трофейных архивов. Они позволили по-новому взглянуть на вопросы иностранной интервенции в 1918-1922 гг. Широко в этом сборнике представлены документы и материалы РКП(б).

Небезынтересно, что составители сборника признают: многие документы даются в извлечениях. Подобный подход объясняется целью - довести до читателей большее количество документов, «представляющих научный интерес» [36, с. XVIII]. Объяснение для своего времени вполне приемлемое. Но с позиций современного исторического знания становится ясным, что подразумевается под политическим интересом публикуемых материалов. Купюры являлись тогда надежным приемом подгонки документов под заранее заданный результат.

Много материала в русле исследования деятельности реввоенсоветов, командиров, военных комиссаров, политорганов, партийных организаций можно почерпнуть из двух сборников документов о партийно-политической работе в Красной армии в годы Гражданской войны [37; 38]. Они, по сути дела, являются томами единого издания. Если первый из них посвящен начальному периоду строительства Красной армии и ее партийно-политического аппарата, то второй охватывает этап после VIII съезда РКП(б) до окончания основных боевых действий в Гражданской войне. Обе книги объединяют и сам подход к отбору документального материала, и композиционная преемственность, и общность принципов археографической обработки материалов. В целом данный двухтомник представляет собой весьма солидное и оригинальное издание, содержащее богатую коллекцию документов, позволяющих воссоздать многие аспекты партийно-политической работы в красных соединениях и частях на всех советских фронтах. Здесь же имеется материал и об их противниках - белых. Правда, он изложен в контексте применительно к красным. И собирать его приходится буквально по крупицам.

Кроме того, в 1957 г. началась публикация уникального многотомного издания - «Декреты советской власти» [39; 40], растянувшаяся на двенадцать лет, а в 1958 г. начали издавать протоколы ЦК партии большевиков [41]. В этих изданиях исследователи могут почерпнуть для себя небезынтересный материал фактографического характера.

Следует акцентировать внимание на том, что определенное влияние на некоторый поворот советской исторической науки в сторону социальноисторической проблематики в истории Гражданской войны оказала публикация довольно большого количества региональных сборников документов, приуроченная к сорокалетнему юбилею Октябрьской революции [42; 43] (они стали издаваться и позже [44]). Документы, включенные в данные сборники, имели обширный фактический материал, позволявший судить о процессе адаптации идеи «народной власти» в массовом сознании и психологии, о реакции на это со стороны противоборствующих государственно-политических образований. Появились более трезвые оценки феномена казачества и его роли в антисоветской борьбе.

Между тем в публикации источников имелись жесткие цензурно-идеологические ограничения. Любые попытки выйти за рамки стереотипов, созданных на базе догматизированного марксизма-ленинизма в большевистском его измерении, решительно пресекались. Например, выход в свет сборника «Великая Октябрьская социалистическая революция и победа советской власти в Армении» в 1957 г., на страницах которого были представлены документы дашнакского правительства, встретили резкой официальной критикой, а обнародование данных источников квалифицировали как политическую ошибку [45, с. $92-$ 101]. Когда же после XXII съезда КПСС режим публикации источников стал несколько мягче, подобный факт рассматривался уже как сильная сторона издания [46, с. 546-547]. Однако требование соответствующего комментирования «вражеских» документов выполнялось неукоснительно и служило рецептом их использования для исследователей. 
В целом же, при работе с документами анализируемых выше сборников необходимо:

- вводить коэффициент корреляции на информационно-психологическое противоборство, которое активно вели в 1918-1920 гг. и красные, и белые. А оно, как известно, априори подразумевало сознательное искажение информации;

- учитывать, что к моменту подготовки к печати документов, вошедших в анализируемые сборники, существовал определенный критерий их отбора, так или иначе соответствовавший оценочной логике событий, сложившейся в исторической науке к тому времени. Дело в том, что политическим руководством страны была предложена шкала приоритетов в трактовке событий Гражданской войны более демократичная, чем в 1930-1950 гг., но не менее обязательная для исполнения. Именно поэтому в сборниках немало места уделено главенству демонстрации руководящей роли коммунистической партии в достижении победы над белыми.

Серьезное приращение источниковой базы - выход в свет некоторых работ крупных политических и военных деятелей партии, военачальников, погибших в годы сталинских репрессий [47; 48; 49]. Кроме них, изданы первые две из трех книг воспоминаний командарма Первой конной армии С.М. Буденного [50], а также М.Д. Бонч-Бруевича, царского генерала, одним из первых перешедших на сторону советской власти [51]. Есть небезынтересные данные и в других изданных воспоминаниях участников Гражданской войны $[52 ; 53]$. Более того, даже были изданы мемуары бывшего заместителя начальника деникинского Осведомительно-агитационного агентства Генерального штаба полковника Б.Энгельгардта [54]. Неординарный источник - опубликованный труд С.С. Каменева, являвшегося одно время Главнокомандующим всеми вооруженными силами Советской республики [55].

Появление большого количества трудов историографического плана, в которых иеленаправленно рассматривалась история изучения истории Гражданской войны, и издание научно-справочных и библиографических трудов. История истории изучения рассматриваемой темы в период хрущевской оттепели характеризуется тем, что появилось определенное количество трудов историографического плана, в которых содержатся и некоторые материалы по историографическому осмыслению Гражданской войны [56, с. 3-7; 57, с. 70-86].

Относительно научно-справочных изданий и библиографических трудов отметим следующее: они стали важным подспорьем в повышении качества научных исследований по истории Гражданской войны. Именно в данных публикациях предпринимались попытки исправить некоторые деформации, порожденные реалиями культа личности И.В. Сталина, рельефно проявлявшиеся в советской науке истории [58; 59; 60; 61] (в формах, присущих научносправочным и научно-библиографическим изданиям). То же самое можно сказать и о некоторых археографических публикациях [39, с. 67-79].

Таким образом, советская историческая наука, глотнув в период хрущевской оттепели глоток свободы творчества (небольшой и ненадолго), развивалась в таких условиях, которые можно считать в основном благоприятными для исследований проблематики истории российской Гражданской войны.

\section{СПИСОК ЛИТЕРАТУРЫ:}

1. Советское общество: возникновение, развитие, исторический финал: В 2-х т. / Науч. ред. В.С. Лельчук. Т. 1. От вооруженного восстания в Петрограде до второй сверхдержавы мира. М.: Российск. гос. гуманит. ун-т, 1997. 510 с. Т. 2. Апогей и крах сталинизма. М.: Российск. гос. гуманит. ун-т, 1997. 761 с.

2. Пихоя Р.Г. Советский Союз: история власти. 1945-1991. Изд. второе, испр. и доп. Новосибирск: Сибирский хронограф, 2000. 692 с.

3. Аксютин Ю.В., Пыжиков А.В. Постсталинское общество: проблема лидерства и трансформации власти. М.: Научная книга, 1999. 413 с.

4. Храмкова Е.Л. Культура России 1941-1945 гг.: отечественная историография рубежа XX-XXI веков. Самара: Научно-технический центр, 2006. 470 с.

5. Ефремов В.Я. Деятельность властных структур по укреплению морального духа Вооруженных сил советского государства (1918-1991 гг.): историографическое исследование. Самара: Изд-во СНЦ РАН, 2007. $376 \mathrm{c}$.

6. Ипполитов Г.М. Летопись братоубийства. Очерки советской историографии Гражданской войны на юге России (1918-1985 гг.); послесловие С.Н. Полторака. Самара, 2009. 517 с.

7. Бобкова Е.Ю. Политическое воспитание личного состава Красной армии в межвоенный период (1920-е - июнь 1941 гг.): очерки отечественной историографии. Изд. 2, доп. Montreal: Accent graphics communications, 2012. $192 \mathrm{c}$.

8. О культе личности и его последствиях. Доклад Первого секретаря ЦК КПСС тов. Н.С. Хрущева ХХ съезду Коммунистической партии Советского Союза 25 февраля 1956 г. // Известия ЦК КПСС. 1989. № 3. C. $128-175$.

9. Власть и диссиденты. Из документов КГБ и ЦК КПСС / Архив нац. безопасности при Ун-те Дж. Вашингтона (США), Московская Хельсинкская группа. М.: МХГ, 2006. 282 c.

10. Аксютин Ю.В. Хрущевская оттепель и общественные настроения в СССР в 1953-1964 гг. М.: РОССПЭН, 2010. $622 \mathrm{c.}$

11. Никита Сергеевич Хрущев. Материалы к биографии. М.: Политиздат, 1989. 372 с.

12. Зубкова Е. Маленков, Хрущев и «оттепель»// Коммунист. 1990. № 14. С. 86-95.

13. Жуков Ю.Н. ХХ съезд КПСС: четыре десятилетия спустя // Крайности истории и крайности историков. М., 1997. С. 208-227.

14. Сидорова Л.А. Оттепель в исторической науке: советская историография первого послесталинского десятилетия. М.: Памятники исторической мысли, 1997. 288 с.

15. Всесоюзное совещание о мерах по улучшению подготовки научно-педагогических кадров по историческим наукам. М.: Наука, 1964. 518 с.

16. Коммунист. 1958. № 16. С. 86.

17. Каганович Л.М. За большевистское изучение истории партии. Речь Л.М. Кагановича, произнесенная 1 декабря на собрании, посвященном десятиле- 
тию Института красной профессуры // Советская Сибирь. 1931. 15 дек. № 336 (3682).

18. ХХ съезд КПСС и задачи исследования истории партии // Вопросы истории. 1956. № 3. С. 3-14.

19. За творческое изучение истории Советских Вооруженных сил // Вопросы истории. 1958. № 2. C. $3-13$.

20. Новые документы В.И. Ленина: Постановления СНК, записки, удостоверения (окт. 1917 - янв. 1918 г.) // Исторический архив. 1957. № 5. С. 3-20.

21. Доклады И.И. Вацетиса В.И. Ленину (февр. май 1919 г.) // Исторический архив. 1958. № 1. C. 41-75.

22. Из переписки М.В. Фрунзе с В.И. Лениным (1919-1920 гг.) // Исторический архив. 1958.№ 3. C. $32-40$.

23. Сокровищница великих идей ленинизма. М.: Политиздат, $1968.206 \mathrm{c}$.

24. Печать в СССР в 1961 году: статматериалы. М.: Изд-во Всесоюзной книжной палаты, 1961. 180 с.

25. Волкогонов Д.А. Ленин: политический портрет. Кн. 1. М.: Новости, 1994. 480 с.

26. Программы Коммунистической партии Советского Союза [Резолюции и постановления XXII съезда КПСС 17-31 окт. 1961 г.] // КПСС в резолюциях и решениях съездов, конференций и пленумов ЦК. Изд. 8-е, доп. и испр. М., 1972. Т. 8. С. 196-325.

27. Обсуждение вопросов методологии истории на расширенных заседаниях секции общественных наук Президиума АН СССР 3 и 6 января 1964 года // Вопросы истории. 1964. № 5. С. 23-66.

28. «Они за Россию, и мы за Россию». Патриотическое воспитание военнослужащих в годы гражданской войны в России: историография проблемы: монография / А.В. Горожанин, В.Я. Ефремов, Г.М. Ипполитов, В.В. Рыбников. Самара: Изд-во НТЦ, 2003. $189 \mathrm{c.}$

29. КПСС о Вооруженных силах Советского Союза 1917-1958. М.: Госполитиздат, 1958. 419 с.

30. Боевое содружество трудящихся зарубежных стран с народами Советской России (1917-1922). Т. 1 / ред. Г.В. Шумейко. М.: Советская Россия, 1957. $569 \mathrm{c}$.

31. Из истории ВЧК: 1917-1921: Сб. документов. М.: Изд-во «Политическая литература», 1958. $511 \mathrm{c.}$

32. Отчет Реввоенсовета Республики за 19171919 гг. // Исторический архив. 1956. № 1. С. 132-155.

33. Коммунистические листовки и воззвания к солдатам Антанты // Исторический архив. 1958. № 1. С. $26-40$.

34. Сидорова Л.А. Инновации в отечественной историографии: опыт рубежа $50-x-60$-х годов // Проблемы источниковедения и историографии: Материалы II Научных чтений памяти академика И.Д. Ковальченко. М.: Наука, 2000. С. 401-410.

35. Из истории гражданской войны в СССР. Сборник документов и материалов. 1918-1922. В 3-х т. / ред. коллегия: Г.А. Белов и др. Т. 1: Май 1918 март 1919. М.: Советская Россия, 1960. 832 с. Т. 2: Март 1919 - февраль 1920. М.: Советская Россия, 1961. 895 с. Т. 3: Февраль 1920 - октябрь 1922. М., Советская Россия, 1961.875 с.

36. Из истории гражданской войны в СССР Сборник документов и материалов. 1918-1922. В 3 т.
/ ред. коллегия: Г.А. Белов и др. Т. 1: Май 1918 март 1919. М.: Советская Россия, 1960. С. XVIII.

37. Партийно-политическая работа в Красной армии (апрель 1918 - февраль 1919): документы. М.: Воениздат, $1961.360 \mathrm{c}$.

38. Партийно-политическая работа в Красной армии (март 1919-1920 гг.): документы. М.: Воениздат, 1964. $536 \mathrm{c}$.

39. Декреты Советской власти. Т. 1. 25 октября 1917 г. - 16 марта 1918 г. М.: Гос. изд-во политической литературы, 1957. 626 с.

40. Декреты Советской власти. Т. II. 17 марта 10 июля 1918 г. М.: Гос. изд-во политической литературы, $1959.632 \mathrm{c}$.

41. Протоколы Центрального Комитета РСДРП (б). Август 1917 - февраль 1918. М.: Гос. изд-во политической литературы, $1958.308 \mathrm{c}$.

42. Борьба трудящихся Черниговщины за власть Советов (1917-1919 гг.): Сборник документов и материалов к 40-летию Великой Октябрьской соц. революции / сост. Г.П. Петрова, И.И. Рабинович, Е.П. Тессен. [Предисл. А.И. Левенко и И.Н. Гирмана]. Чернигов, 1957. $475 \mathrm{c}$.

43. Борьба трудящихся Юго-Осетии за Советскую власть. 1917-1921: Документы и материалы / [Собрал И.Н. Цховребов]. Сталинири: Госиздат Юго-Осетии, 1957. $287 \mathrm{c}$.

44. Южный фронт (май 1918 - март 1919). Борьба советского народа с интервентами и белогвардейцами на юге России. Сб. документов / сост. Л.И. Буханова и др.; ред. колл.: Е.А. Хмелевский (отв. ред. ) и др. Ростов: Ростовское кн. изд-во, $1962.410 \mathrm{c}$.

45. Правовое воспитание личного состава силовых структур Российского государства: более 80 лет истории изучения (1918-2000 гг.): монография: в 2 т. Т. 2. Историография периода Великой Отечественной войны, движения СССР к историческому финалу. Россия постсоветская: историография проблемы / А.В. Горожанин, Г.М. Ипполитов, В.В. Рыбников, М.В. Хачатурян. Самара: Изд-во Самарского юридического ин-та Минюста России, 2003. 202 с.

46. Советская историческая наука от XX к XXII съезду КПСС. (рец.) // История СССР. 1962. С. 546-547.

47. Якир И.Э. Воспоминания о Гражданской войне. М.: Изд-во Минобороны СССР, 1957. 39 с.

48. Блюхер В.К. Статьи и речи М.: Воениздат, 1963. $232 \mathrm{c}$.

49. Тухачевский М.Н. Избранные произведения: в 2 т. М.: Воениздат, 1964. Т. I (1919-1927 гг.). 240 с. T. II (1928-1937 гг.). 264 с.

50. Буденный С.М. Пройденный путь. Книга первая: М.: Воениздат, 1958. 448 с. Книга вторая: М.: Воениздат, $1965.392 \mathrm{c.}$

51. Бонч-Бруевич М.Д. Вся власть Советам! М.: Воениздат, 1958. $192 \mathrm{c}$.

52. Этапы большого пути: воспоминания о Гражданской войне. М.: Воениздат, 1963. 568 c.

53. Ковтюх В.М. Гражданская война на Кубани // Военно-исторический журнал. 1964. № 2. С. 81-93.

54. Энгельгардт Б. Потонувший мир // Военноисторический журнал. 1964. № 1. С. 70-84; № 5. C. 72-73; № 7. C. 75-84; № 9. C. 70-81.

55. Каменев С.С. Записки о Гражданской войне и военном строительстве. М.: Воениздат, 1963. 264 с. 
Ипполитов Г.М., Ефремов В.Я.

Условия выполнения советских исторических исследований.

07.00.00 - исторические науки и археология

56. За творческое изучение истории Советских Вооруженных Сил // Военно-исторический журнал. 1959. № 2. C. 3-7.

57. Нечкина М., Поляков Ю., Черепнин Л. Некоторые вопросы истории советской исторической науки // Коммунист. 1961. № 9. С. 70-86.

58. Советская страна в период гражданской войны, 1918-1920. Библиографический указатель документальных публикаций. под ред. Е.Н. Городецкого. М.: Изд-во Всесоюз. Кн. палаты, 1961. 575 с.

59. Прохоров В.П. Вопросы партийно-политической работы в трудах В.И. Ленина и решениях КПСС. Указатель лит-ры / сост. П.П. Прохоров. М., 1959. 91 с.

60. Военные вопросы в решениях КПСС: аннотированный библиографический указатель. М.: Гос. бка им. В.И. Ленина, 1962. 117 с.

61. Иваницкая Т.В., Сазонов М.С. Периодизация истории советской археографии // Труды Московского историко-архивного института. Т. 15. М., 1962. C. $67-79$.

\title{
IMPLEMENTATION CONDITIONS OF THE SOVIET HISTORICAL RESEARCH ON ISSUES OF THE CIVIL WAR HISTORY IN RUSSIA (1918-1922) IN THE SECOND HALF OF THE 1950S - THE FIRST HALF OF THE 1960S
}

G.M. Ippolitov, doctor of historical sciences, professor of the Chair of Philosophy

Povolzhskiy State University of Telecommunications \& Informatics, Samara (Russia)

V.Y. Efremov, doctor of historical sciences, professor of the Chair of Social Sciences and Humanities Volsk Military Institute (Branch) of Logistics of Khroulyov Military Academy of Logistics, Volsk (Russia)

\begin{abstract}
The Khrushchev thaw» is a unique period in the history of the Soviet State. It was the Decade in which attempts have been made to at least to localize the negative impact created by the Stalinist political system functioned in the country (the so-called «Stalin's cult of personality»). Soviet power structures and the ruling Communist Party in the country tried to clean all areas of Soviet society life including the spiritual one from its negative consequences. It also influenced the Soviet historical science. It attempts to perform historical, historiographical and source research on the principles of genuine objectivity and Historicism (though such attempts, eventually in the form of embryonic tendencies that gradually eliminated). In such a situation in historiography the study of history of the Russian civil war (November 1917-1922) was one of the priorities. The article summarises the main conditions developed in the study of the Civil War in Russia during the Khrushchev Thaw (the second half of the 1950s - the first half of the 1960s.). Some of the authors' ideas are debatable.

Keywords: historiography; Soviet historical science; Russian Civil War; XXth Congress of the Communist Party of the Soviet Union (1956); Khrushchev Thaw; breakthrough in the source base studies; collections of documents; censorship ideological restrictions.
\end{abstract}

УДК 94(470.40)

\section{НЕОФИЦИАЛЬНАЯ РЕЛИГИОЗНОСТЬ «МУСУЛЬМАНСКИХ»НАРОДОВ СРЕДНЕГО ПОВОЛЖЬЯ И ПРИУРАЛЬЯ В 1960-1970-Е ГОДЫ}

(C) 2016

А.К. Идиатуллов, кандидат исторических наук, доцент кафедры географии и экологии

Ульяновский государственный педагогический университет имени И.Н. Ульянова, Ульяновск (Россия)

Л.Н. Галимова, доктор исторических наук, профессор кафедры гуманитарных и социальных дисциплин Ульяновский институт гражданской авиаџии имени главного мариала авиаџии Б.П. Бугаева, Ульяновск (Россия)

Аннотация. В последнее время заметно вырос интерес к исламу и мусульманскому праву. Ислам играет весьма значительную роль в современном мире. Тесная взаимосвязь правовых и религиозных предписаний ислама, религиозная основа мусульманского права, его «мусульманский» характер не вызывают сомнений.

В статье анализируется неофициальная религиозность «мусульманских» народов Среднего Поволжья и Приуралья в 60-70-е годы XX в. Данное время во взаимоотношениях власти и исламских институтов характеризуется относительной либеральностью. Уполномоченными в Среднем Поволжье и Приуралье отмечается восстановление и развитие как официальных, разрешённых в СССР, так и не вполне традиционных для советского времени исламских практик. В отчётах фигурируют такие формы неофициальной религиозности, как неоязычество, «бродячие» муллы, неофициальные мусульманские группы, поклонения местам захоронения суфиев и святым источникам. Уполномоченными, партийными органами власти, официальным мусульманским духовенством все формы неофициальной религиозности сурово пресекались. Нередко ислам становился предметом интереса «мусульманских» народов как культурный компонент их традиционного мировоззрения, а не как религиозная система. Авторы считают, что исламская религиозность переместилась с этнокультурного на личностный, неофициальный уровень.

Ключевые слова: Среднее Поволжье; Приуралье; Союз Советских Социалистических Республик; культура; ислам; религиозность; Коран; верующие; паломничества; религиозные течения; политика; советский период; 1960-е годы; 1970-е годы. 